\title{
Abya Yala Como Território Epistêmico: Pensamento Decolonial Como Perspectiva Teórica
}

Almeida, Eliene Amorim de ${ }^{1}$

Silva, Janssen Felipe $\mathrm{da}^{2}$

\section{Resumo}

Este artigo objetiva tratar sobre a Perspectiva Teórica do Pensamento Decolonial enquanto chave de leitura da realidade complexa da América Latina, tomando-a como território de enunciação epistêmica como de análise. Partimos do pressuposto de que Pensamento Decolonial constrói uma inteligibilidade outra da história e da ciência moderna no contexto da invasão da América a partir de 1492, o que nos possibilita analisarmos a história do contato entre os povos originários da América Latina e os europeus, mostrando como os povos originários entram para o sistema mundo/moderno/colonial racializados na condição de índios e a partir do conceito de Diferença Colonial e Desobediência Epistêmica mostramos suas resistências ao Colonialismo e à Colonialidade.

Pensamento Decolonial. Colonialidade. Diferença Colonial. Desobediência Epistêmica

\section{Abstracto}

Este artículo tiene como objetivo abordar la Perspectiva Teórica del Pensamiento Descolonial, como clave para la lectura de la compleja realidad de Latinoamérica, tomándola como territorio de enunciación epistémico de análisis. Partimos del presupuesto que el Pensamiento Decolonial construye una otra inteligibilidad de la historia y de la ciencia moderna en el contexto de la invasión de América, desde el 1492, lo que nos permite analizar la historia del contacto entre los pueblos originarios de América Latina y los europeos, mostrando cómo los pueblos originarios se adentran en el sistema mundo/moderno/ colonial racializados bajo la condición de indios y desde el concepto de Diferencia Colonial y Desobediencia Epistémica demostramos sus resistencias al Colonialismo y a la Colonialidad.

\section{Pensamiento Decolonial. Colonialidad. Diferencia Colonial. Desobediencia epistémica.}

\footnotetext{
${ }^{1}$ Mestra (2002) em Educação pela Universidade Federal de Pernambuco (UFPE). Doutoranda do Programa de Pós-graduação em Educação da UFPE. Pertence ao Grupo de Estudos Pós-Coloniais LatinoAmericanos, Teoria da Complexidade e Educação. Professora da Faculdade de Filosofia Ciências e Letras de Caruaru (FAFICA).

2 Doutor (2007) em Educação pela Universidade Federal de Pernambuco (UFPE). Professor do Centro Acadêmico do Agreste (CAA) da UFPE. Coordenador do grupo de Estudos Pós-Coloniais LatinoAmericanos, Teoria da Complexidade e Educação Professor Permanente do Programa de Pós-graduação em Educação e Colaborador do Programa de Pós-graduação em Educação Contemporânea do CAA da UFPE.
} 


\section{Introdução}

Este artigo tem por objetivo discorrer sobre a Perspectiva Teórica do

Pensamento Decolonial enquanto chave de leitura da realidade complexa da América Latina, isto é, tomando a Abya Yalai tanto como território de enunciação epistêmica como de análise.

Partimos do pressuposto de que Pensamento Decolonial constrói uma inteligibilidade outra da história e da ciência moderna no contexto da invasão da América a partir de 1492, o que nos possibilita analisarmos a história do contato entre os povos originários da América Latina e os europeus, mostrando como os povos originários entram para o sistema mundo/moderno/colonial racializados na condição de índios e a partir do conceito de Diferença Colonial e Desobediência Epistêmica mostramos suas resistências ao Colonialismo e à Colonialidade.

\section{O Pensamento Decolonial - uma Inteligibilidade Outra da História e da Ciência}

O que estamos tratando como Pensamento Decolonial é um movimento de resistência- teórico, epistêmico, cultural, prático e político -, à lógica da Modernidade/Colonialidade. É teórico e epistemológico porque ao estudar as heranças/feridas coloniais da América Latina em diálogo com a teoria do sistema-mundo-moderno de Wallerstein (CASTRO-GÓMEZ; GROSFOGUEL, 2007, p. 10) denuncia e questiona a geopolítica do conhecimento e a Colonialidade do Poder oferecendo às ciências humanas e sociais uma inteligibilidade outra ao Projeto Moderno, desvelando sua outra face que é a Colonialidade (QUIJANO, 2005, 2010). É prático e político porque a Rede Modernidade/Colonialidade "no se especializa sólo en publicar libros dirigidos a expertos, sino que participa también en vários proyectos académico-políticos. Algunos de sus miembros se encuentran vinculados con el movimiento indígena en Bolivia y Ecuador, y otros organizan actividades en el marco del Foro Social Mundial" (CASTRO-GÓMEZ; GROSFOGUEL, 2007, p. 12).

A Rede Modernidade/Colonialidade (M/C) se articula desde a década de 1990, a partir de vários encontros e reuniões entre intelectuais de diferentes países da 
América Latina e de diversas áreas do conhecimento, sendo considerado, portanto, um pensamento transnacional e transdisciplinar, sem se pretender universal. Seus principais expoentes são: Aníbal Quijano; Arturo Escobar; Catherine Walsh; Edgardo Lander; Enrique Dussel; Maldonado Torres; Ramón Grosfoguel; Santiago Castro Gomes; Walter Mignolo. São todos intelectuais cujo Lócus da Enunciação é a América Latina, não apenas como espaço geográfico, mas como um território sócio-político, cultural e epistêmico forjado pelo Colonialismo, no contexto da Diferença Colonial (MIGNOLO, 2003), que vive em tensão da Colonialidade, mas também carrega o potencial da Decolonialidade.

O Pensamento Decolonial é uma vertente da crítica pós-colonial, especialmente das teorias surgidas na Ásia e África, no contexto das lutas de vários países colonizados pela libertação, produzindo reflexões acerca do que representou o Colonialismo para os países colonizados pela Europa. Primeiramente, o foco da crítica dos Estudos Pós-Coloniais recai sobre a influência eurocêntrica nas artes e na literatura, depois se expande para o campo da Economia Política e das Ciências Sociais questionando os cânones ocidentais da ciência moderna. Segundo Neves,

as primeiras utilizações do termo pós-colonial, nos anos 70 , pertencem ao domínio da crítica literária e daqui provêm os seus pais fundadores: Edward Said, Homi Bhabha e Gayatri Spivak. Igualmente da crítica literária tem origem um texto considerado fundamental para a disciplina, «The Empire writes back» de Bill Ashcroft, Helen Tiffin e Gareth Griffiths (2009, p. 236).

Para Ballestrin (2013, p. 92) existe um entendimento compartilhado sobre a importância, a atualidade e o ineditismo dos Estudos Pós-Coloniais, como portavozes que intercederam pelo colonizado quando estes não tinham vozes, com os pioneiros trabalhos de

Franz Fanon (1925-61) - psicanalista, negro, nascido na Martinica e que participou do processo de libertação nacional, autor de "Os condenados da terra" (1961), Aimé Césaire (19132008) - poeta, negro, também nascido na Martinica com seu livro "Discurso sobre o colonialismo" (1950) e Albert Memmi (1920) escritor e professor, nascido na Tunísia, de origem judaica "Retrato do colonizado precedido de retrato do colonizador" (1947). A estes três clássicos, soma-se a obra "Orientalismo" (1978) de Edward Said (1935-2003), crítico literário de origem palestina e militante da causa. 
No campo das ciências sociais, o Pós-Colonialismo questiona a perspectiva teórica que divide o globo terrestre em primeiro, segundo e terceiro mundos, denunciando seu caráter desenvolvimentista e eurocêntrico; as hierarquias sexuais, raciais e étnicas, os processos culturais e ideológicos trazendo para suas análises teóricas a cultura como elemento determinante das relações econômicas e políticas do capitalismo, caracterizando-o como um sistema cultural, relativizando o determinismo econômico (GROSFOGUEL, 2010). Para Carvalho, a teoria "pós-colonial questiona as relações de poder e as formas de conhecimento que colocaram o sujeito imperial europeu e norte-americano na sua actual situação de privilégio; os efeitos de dominação da razão instituída pelo Ocidente" (2004, p. 44).

$\mathrm{Na}$ década de 1980, o Grupo sul asiático de Estudos Subalternos, sob a liderança de Ranajit Guha, torna-se conhecido fora da Índia, especialmente através dos autores Partha Chatterjee, Dipesh Chakrabarty e Gayatri Chakrabarty Spivak, esta última, em 1985, publicou o artigo "Pode o subalterno falar?", que é considerado cânone do pensamento Pós-Colonial (BALLESTRIN, 2013) e irá contribuir para que o pós-colonialismo se afirme como um movimento de caráter político, intelectual. Nessa mesma década, em um contexto de globalização, a crítica pós-colonial vai convergir com os Estudos Culturais na Inglaterra e nos Estados Unidos, com suas "categorias de cultura, identidade (classe/etnia/gênero), migração e diáspora" (BALLESTRIN, 2013, p. 93) fortalecendo a crítica às lógicas coloniais modernas. Os autores, expoentes desse pensamento mais conhecidos no Brasil, segundo Balestrin (2013), são: o indiano Homi Bhabha com a obra "O local da cultura"; o jamaicano Stuart Hall com o livro "Da Diáspora" e, o inglês Paul Gilroy, que escreveu o "Atlântico Negro", obras que foram traduzidas para o português e tiveram repercussão nas ciências sociais brasileiras.

O Pensamento Decolonial tem suas origens na década 1990, nos Estados Unidos com a "reimpressão do texto hoje clássico de Anibal Quijano 'Colonialidad y modernidad-racionalidad'” (BALLESTRIN, 2013, p. 94) quando um grupo de intelectuais latino-americanos e americanistas que viviam nos EUA, inspirado, principalmente no Grupo Sul-Asiático dos Estudos Subalternos, 
fundou o Grupo Latino-Americano dos Estudos Subalternos, conforme pode ser observado no trecho do "Manifiesto inaugural del Grupo Latinoamericano de Estudios Subalternos",

El trabajo del Grupo de Estudios Subalternos, una organización interdisciplinaria de intelectuales sudasiáticos dirigida por Ranajit Guha, nos ha inspirado a fundar un proyecto similar dedicado al estudio del subalterno en América Latina. El actual desmantelamiento de los regímenes autoritarios en Latinoamérica, el final del comunismo y el consecuente desplazamiento de los proyectos revolucionarios, los procesos de redemocratización, las nuevas dinámicas creadas por el efecto de los mass media y el nuevo orden económico transnacional: todos estos son procesos que invitan a buscar nuevas formas de pensar y de actuar políticamente. A su vez, la redefinición de las esferas política y cultural en América Latina durante los años recientes ha llevado a varios intelectuales de la región a revisar algunas epistemologías previamente establecidas en las ciencias sociales y las humanidades. La tendencia general hacia la democratización otorga prioridad a una reconceptualización del pluralismo y de las condiciones de subalternidad al interior de sociedades plurales. (GRUPO LATINOAMERICANO DE ESTUDOS SUBALTERNOS, 1998, s/p).

É nesse contexto que a América Latina entra para o debate dos Estudos Póscoloniais, entretanto como afirmam Castro-Gomez e Mendieta (1998, p. 17) "a voz mais crítica e radical do grupo, Walter Mignolo", demonstra seu descontentamento com os Estudos Subalternos, pois entendia que o lócus da enunciação das teses dos teóricos indianos são as heranças coloniais do império britânico e não deveriam simplesmente ser assumidas e traduzidas para uma análise das heranças coloniais latino-americanas, "alertando para a necessidade de buscar uma categorização crítica que tenha seu Lócus de Enunciação a América Latina" (CASTRO-GOMEZ; MENDIETA, 1998, p. 17).

Segundo os autores, Mignolo analisava que a história de dominação e de resistência da América Latina estava oculta no debate pós-colonial, já que para ele o continente foi fundamental para o desenvolvimento do capitalismo mundial, sendo o primeiro espaço geográfico cultural a sofrer as consequências do sistema colonial/imperial moderno, além disso, "os teóricos dos estudos regionais estadounidenses e dos estudos subalternos indianos demonstravam 
incapacidade em romper com a episteme - a seu ver, ainda centrada no Norte" (1998, p. 17).

Assim, o Grupo Latino-Americano de Estudos Subalternos foi desagregado devido às divergências teóricas, a principal delas a oposição entre aqueles que consideravam a subalternidade uma crítica pós-moderna, o que para 0 Pensamento Decolonial representa uma crítica eurocêntrica ao eurocentrismo (GROSFOGUEL, 2010) e os que compreendiam como uma crítica ao eurocentrismo por parte dos saberes silenciados e subalternizados, ou seja, uma crítica decolonial. Após a desagregação do grupo em 1998, começa a ocorrer os primeiros encontros entre os membros que posteriormente formariam a Rede Modernidade/Colonialidade.

A Rede Modernidade/Colonialidade se distingue dos demais Estudos PósColoniais ao adotar o termo Decolonialidade para desenvolver sua crítica à modernidade, ao invés de pós-colonialismo, já que tem como objetivo

\begin{abstract}
trascender la suposición de ciertos discursos académicos y políticos, según la cual, con el fin de las administraciones coloniales y la formación de los Estados-nación en la periferia, vivimos ahora en un mundo descolonizado y poscolonial. Nosotros partimos, en cambio, del supuesto de que la división internacional del trabajo entre centros y periferias, así como la jerarquización étnico-racial de las poblaciones, formada durante varios siglos de expansión colonial europea, no se transformó significativamente con el fin del colonialismo y la formación de los Estados-nación en la periferia. Asistimos, más bien, a una transición del colonialismo moderno a la colonialidad global, proceso que ciertamente ha transformado las formas de dominación desplegadas por la modernidad, pero no la estructura de las relaciones centro-periferia a escala mundial (CASTRO-GOMES; GROSFOGUEL, 2007, p. 13).
\end{abstract}

$\mathrm{Na}$ fala dos autores é possível observar a distinção entre Colonialismo e Colonialidade. Para essa perspectiva teórica, o Colonialismo teve um fim com as independências dos países colonizados, enquanto que a Colonialidade seria a lógica e o legado colonial, herdados do colonialismo, que penetrou nas estruturas e instituições e também nas mentalidades, imaginários, subjetividades e epistemologias, e até hoje dão forma e conteúdo às sociedades atuais. É importante destacar que a Modernidade e a Colonialidade são faces de uma 
mesma moeda, ou seja, a Colonialidade é constitutiva da Modernidade, e não derivada. A Colonialidade é a face obscura da Modernidade.

Diferente do Colonialismo que teve datas marcadas para seu fim nos países que foram invadidos pela Europa, a Colonialidade não está circunscrita ao tempo e ao espaço do período das grandes navegações ou das independências, mas acompanha todo processo subsequente caracterizado pelas mudanças do capitalismo, acompanhada pela racialização da humanidade; pela instalação dos Estados-nação; pela ascensão da razão única e universal; e, para completar o ciclo da Colonialidade, pela constituição de subjetividades hierarquizadas. Para Grosfoguel (2010), o conceito de Colonialidade permite-nos compreender a continuidade das formas coloniais de dominação após o fim das administrações coloniais, produzidas pelas culturas coloniais e pelas estruturas do sistemamundo/capitalista/ moderno/colonial.

A Colonialidade encontra-se em cada âmbito da existência humana: no trabalho; no sexo; na subjetividade; na autoridade; no conhecimento eurocêntrico; na escola e no seu currículo, e se articula a vários tipos de hierarquias: étnicas, raciais, sexuais, gênero, conhecimento, de linguagem, religiosa, portanto, a Colonialidade envolve um complexo sistema de hierarquias, por isso, a rede Modernidade/Colonialidade compreende que além da Colonialidade do poder, há também as dimensões do saber, do ser e da natureza,

es entonces una estructura compleja de niveles entrelazados: control de la economía; control de la autoridad; colonialidad del poder; control de la naturaleza y de los recursos naturales; control del género y la sexualidad; control de la subjetividad y del conocimiento (MIGNOLO, 2010, p. 12).

O conceito de Colonialidade do poder mostra a continuidade das formas coloniais de dominação após o fim das administrações coloniais, produzidas pelos invasores coloniais e pelas estruturas do sistema-mundo capitalista moderno/colonial e também possui uma capacidade explicativa que atualiza e contemporiza processos que supostamente teriam sido apagados, assimilados ou superados pela modernidade. Segundo Quijano, a Colonialidade do Poder

consiste, en primer término, en una colonización del imaginario de los dominados. Es decir, actúa en la interioridad de ese imaginario... La represión recayó, ante todo, sobre los modos de 
conocer, de producir conocimiento, de producir perspectivas, imágenes y sistemas de imágenes, símbolos, modos de significación; sobre los recursos, patrones e instrumentos de expresión formalizada y objetivada, intelectual o visual... Los colonizadores impusieron también una imagen mistificada de sus propios patrones de producción de conocimientos y significaciones» (QUIJANO, 1992, p. 438).

Como pode ser observado, a Colonialidade do poder é uma inteligibilidade outra para entender o Projeto moderno na América Latina, compreendendo-o como um Enredoii (GROSFOGUEL, 2010) bem mais amplo e articulado do que a simples relação entre superestrutura e infraestrutura apresentada pelo materialismo histórico, que para Quijano (2010) é a mais eurocêntrica das heranças marxistas. Dussel descreve assim o Projeto Moderno:

1. A civilização moderna autodescreve-se como mais desenvolvida e superior (o que significa sustentar inconscientemente uma posição eurocêntrica). 2. A superioridade obriga a desenvolver os mais primitivos, bárbaros, rudes, como exigência moral. 3. O caminho de tal processo educativo de desenvolvimento deve ser aquele seguido pela Europa (e, de fato, um desenvolvimento unilinear e a Europa o que determina, novamente de modo inconsciente, a "falácia desenvolvimentista"). 4. Como o bárbaro se opõe ao processo civilizador, à práxis moderna deve exercer em último caso a violência, se necessário for, para destruir os obstáculos dessa modernização (a guerra justa colonial). 5. Esta dominação produz vítimas (de muitas e variadas maneiras), violência que é interpretada como um ato inevitável, e com o sentido quase-ritual de sacrifício; o herói civilizador reveste a suas próprias vítimas da condição de serem holocaustos de um sacrifício salvador (o índio colonizado, o escravo africano, a mulher, a destruição ecológica, etecetera). 6. Para o moderno, o bárbaro tem uma "culpa" (por opor-se ao processo civilizador) que permite a "Modernidade" apresentar-se não apenas como inocente, mas como "emancipadora" dessa "culpa" de suas próprias vítimas. 7. Por último, e pelo caráter "civilizatório" da "Modernidade", interpretam-se como inevitáveis os sofrimentos ou sacrifícios (os custos) da "modernização" dos outros povos "atrasados" (imaturos), das outras raças escravizáveis, do outro sexo por ser frágil, etecetera (2005, p. 32).

Os povos que viviam/vivem em Abya Yala foram as primeiras vítimas e os sujeitos desse processo de inferiorização, classificados como povos bárbaros; foram objeto de processos de vários processos seja a dizimação física dos 
indivíduos até a homogeneização cultural, ora através da violência física, ou da catequese, ora através da escola.

Nas análises do pensamento eurocêntrico, assim como na "actual producción intelectual que se denomina a sí misma como estudios, teoría o crítica póscolonial comienza su análisis" (MIGNOLO, 2003, p. 9) sobre a modernidade utilizando como marcos fundantes a Reforma, o lluminismo, a Revolução Francesa e a Revolução Industrial, fenômenos situados nos séculos XVII e XVIII e em países da Europa do Norte, sobretudo, Inglaterra, Alemanha e França, ou seja, acontecimentos eminentemente intraeuropeus, "dejando a un lado el período crucial y constitutivo de la modernindade/colonialidad que representa el siglo XVI", (MIGNOLO, 2003, p. 9); como pode ser observado, aqui de novo, o Pensamento Decolonial também se distancia dos Estudos Pós-Coloniais.

$\mathrm{Na}$ perspectiva Decolonial tais eventos históricos são precedidos por uma primeira modernidade, situada nos séculos XV e XVI, com a conquista e colonização da América e a consequente formação do Sistema-Mundo-Moderno, processos inaugurados por Espanha e Portugal (DUSSEL, 1994, 2005), portanto a Modernidade se inicia "quando se deram as condições históricas de sua origem efetiva: 1492 - sua empírica mundialização, a organização de um mundo colonial e o usufruto da vida de suas vítimas, num nível pragmático e económico" (DUSSEL, 2005, p. 33). A América é compreendida, assim, como parte constitutiva da modernidade, uma exterioridade que lhe é interior.

Segundo Dussel, o conquisto, logo existo antecipou-se ao 'penso, logo, existo' cartesiano em 150 (cento e cinquenta) anos com a expansão colonial portuguesa e espanhola. Sobre isso afirma o autor:

para Habermas, como para Hegel, el descubrimiento de América no es un determinante constitutivo de la Modernidad. Deseamos demostrar lo contrario. La experiencia no sólo del "Descubrimiento", sino especialmente de la "Conquista" será esencial en la constitución del "ego" moderno, pero no sólo como subjetividad, sino como subjetividad "centro" y "fin" de la historia (DUSSEL, 1994, p. 21).

É nesse contexto histórico onde são constituídas novas identidades sociais, geoculturais, raciais, tais como: ocidente-oriente; primitivo-civilizado; tradicionalmoderno; mágico/mítico-racional (QUIJANO, 2005). 
Para o Pensamento Decolonial, a Modernidade é um fenômeno eminentemente europeu e não planetário, mas que se tornou hegemônico pela Colonialidade do Poder, compondo-se a partir desse contexto como um novo paradigma de vida cotidiana, de compreensão da história, da ciência e da religião (MIGNOLO, 2005). Nesse novo paradigma, a Europa se apresenta como a civilização moderna e se autodescreve como superior e desenvolvida, como o novo e o mais avançado da espécie humana, enquanto que os demais povos são atrasados, primitivos, bárbaros. A Europa para se constituir como humanidade moderna precisava criar uma sub-humanidade, assim colocou-se a questão se os indígenas tinham alma, como nos informa Santos:

os índios têm alma? Quando o Papa Paulo II respondeu afirmativamente na bula Sublimis Deus, de 1537, fê-lo concebendo a alma dos povos selvagens como receptáculo vazio, uma anima nullius, muito semelhante à terra nullius, o conceito de vazio jurídico que justificou a invasão e ocupação dos territórios indígenas (2010, p. 37).

Assim, como as terras em que viviam os povos indígenas estavam vazias, os portugueses e espanhóis, entendiam que suas "almas" também eram vazias e precisavam ser "salvas" dessa condição, mesmo que para isso fosse necessário ser empregado o genocídio, ou o etnocídio, já que "a negação de uma parte da humanidade é sacrificial, na medida em que constitui a condição para a outra parte da humanidade se afirmar enquanto universal" (SANTOS, 2010, p. 37).

O Pensamento Decolonial também se distingue dos Estudos Pós-Coloniais, porque compreende que não é suficiente criticar a modernidade e analisar suas heranças coloniais, utilizando os seus próprios cânones. Grosfoguel, criticando o Grupo dos Estudos Subalternos Latino-americano, afirma que

apesar de terem tentado produzir um conhecimento alternativo e radical, eles reproduziram o esquema epistémico dos Estudos regionais nos Estados Unidos. Salvo raras exceções, optaram por fazer estudos sobre a perspectiva subalterna, em vez de os produzir com essa perspectiva e a partir dela. A semelhança da imperial epistemologia dos Estudos regionais, a teoria permaneceu sediada no Norte, enquanto os sujeitos a estudar se encontram no Sul (GROSFOGUEL, 2010, p. 456).

Como pode ser observado, outro elemento importante dessa perspectiva teórica é questionar o lugar/corpo epistêmico, e evidenciar a ego-geo-política e a corpo- 
política do conhecimento, descortinando o território, a cor, raça, etnia, identidade sexual e de gênero, do sujeito cognoscente. $E$ mais do que isso, considerar as epistemologias outras, ou seja, as "perspectivas epistêmicas subalternas" como uma das formas de conhecimento que, "vindo de baixo, origina uma perspectiva crítica do conhecimento hegemónico nas relações de poder envolvidas" (GROSFOGUEL, 2010, p. 459). As perspectivas teóricas que veem os subalternizados apenas como objeto de estudo e não como territórios e sujeitos epistêmicos limitam e constrangem a radicalidade da crítica, ou seja, como já dissemos anteriormente, faz-se uma crítica eurocêntrica ao eurocentrismo.

Para o Pensamento Decolonial, a suposta superioridade do conhecimento europeu foi fundamental para garantir a Colonialidade do poder. A epistemologia moderna produziu não só uma forma de construir conhecimentos, mas promoveu modos de vidas, estabeleceu o que é certo ou errado, definiu formas, conteúdos e valores para a vida cotidiana dos povos colonizados. Os conhecimentos dos povos originários que tiveram seus territórios invadidos a partir de 1492 foram impostos como subalternos, excluídos, omitidos, silenciados e ignorados. No lluminismo, essa condição de povos primitivos foi legitimada pela ideia de que eles estavam na pré-história da humanidade, portanto, seus conhecimentos representavam uma etapa mítica, inferior, pré-moderna e pré-científica do conhecimento humano.

Para a ciência moderna somente o conhecimento gerado nos moldes da ciência e filosofia europeia é considerado como verdadeiro, já que é capaz de fazer abstração de seus condicionamentos espaço-temporais para se localizar em uma plataforma neutra de observação, formando, assim, o que Castro-Gómez chama "la hybris del punto cero", o ideal último do conhecimento científico que significa

ter o poder de nomear pela primeira vez o mundo; de traçar fronteiras para estabelecer quais conhecimentos são legítimos e quais são ilegítimos, definindo quais comportamentos são normais e quais são patológicos. Por isso, o ponto zero é o do começo epistemológico absoluto, mas também o do controle econômico e social sobre o mundo. Localizar-se no ponto zero equivale a ter o poder de instituir, de representar, de construir uma visão sobre o mundo social e natural reconhecida como legítima e autorizada pelo Estado. Trata-se de uma 
representação na qual os "varões ilustrados" se definem a si mesmos como observadores neutros e imparciais da realidade (CASTRO-GOMEZ, 2005a, p. 25).

A epistemologia do ponto zero pretendeu eliminar outras alternativas, produzir, sistematizar e publicizar conhecimentos e construir uma visão hegemônica, universalista, pretensamente neutra e objetiva. Para se estabelecer no ponto zero, em primeiro lugar, as ciências sociais/humanas se apropriaram do modelo da física com a finalidade de criar seu objeto a partir de um tipo de observação imparcial, deslocalizada e asséptica. Na concepção cartesiana, ou seja, o ego cogito: penso, logo existo (DUSSEL, 1994), vê-se expressa a ideia de que a sociedade pode ser observada de um lugar neutro de observação, não contaminado pelas contingências históricas, espaciais e temporais. Dessa forma, a ciência é uma plataforma na qual um observador imparcial se encontre na capacidade de estabelecer as leis que governam tanto ao cosmos como a polis (CASTRO-GOMEZ, 2005b). A teopolítica que fundamentava o conhecimento europeu na Idade Média é substituída pelo homem ocidental e moderno. Esse fundamento das ciências modernas ocidentais torna-se verdade universal. A verdade científica está para além do tempo, do espaço e dos sujeitos que a produz; o acesso privilegiado às leis do universo e a capacidade de produzir conhecimento e teorias científicas estão agora situados na mente do homem ocidental.

Em seguida, rumo ao ponto zero é necessário excluir, subalternizar qualquer outro conhecimento que não corresponda às exigências do método analíticoexperimental. Uma vez instaladas no ponto zero, as ciências do homem e da sociedade passam a construir um discurso sobre a história e a natureza humana; nesse discurso os povos colonizados pela Europa aparecem no nível mais baixo da escala de desenvolvimento.

A epistemologia do ponto zero desconsiderou a produção intelectual e prática dos povos de Abya Yala, mesmo que vários povos tenham demonstrado as riquezas de sua produção cultural e intelectual como é o caso dos Maias que ergueram pirâmides, templos e palácios, demonstrando um conhecimento arquitetônico bastante elaborado. O artesanato também se destacou: fiação de tecidos uso de tintas em tecidos e roupas. Ou ainda, os Incas que desenvolveram 
várias construções com enormes blocos de pedras encaixadas, como templos, casas e palácios, por exemplo, a cidade de Machu Picchu que foi descoberta em 1911 e revelou a estrutura urbana desta sociedade. A agricultura era extremamente desenvolvida, pois plantavam nos chamados terraços (degraus formados nas costas das montanhas). Plantavam e colhiam feijão, milho (alimento sagrado) e batata. Construíram canais de irrigação, desviando o curso dos rios para as aldeias (MENSAGEIRO, 1988).

Ao esconder o Lócus de Enunciação, o paradigma ocidental, ou ego-geopolítica, do conhecimento conseguiu criar um mito sobre um suposto conhecimento universal, único e verdadeiro, encobrindo as estruturas de poder/conhecimento colonial a qual o sujeito que o produz está imbricado. Por isso Mignolo (2008) insiste que a genealogia do Pensamento Decolonial

es realmente diferente a la genealogía de la teoría postcolonial-, que se encuentra en Mahatma Gandhi, W.E.B Dubois, Juan Carlos Mariátegui, Amilcar Cabral, Aimé Cessaire, Frantz Fanon, Fausto Reinaga, Vine Deloria, Jr., Rigoberta Menchú, Gloria Anzaldúa, el Movimiento de los Sin Tierra en Brasil, los zapatistas en Chiapas, los movimientos indígenas y afros en Bolivia, Ecuador o Colombia, el Foro Social Mundial y el Foro Social de las Américas. La genealogía del pensamiento de-colonial es planetaria y no se limita a individuos, sino que se incorpora en movimientos sociales (lo cual nos remite a movimientos sociales indígenas y afros (MIGNOLO, 2008, p. 258).

Mas, Grosfoguel (2010) chama atenção para o fato de não se tratar de uma crítica anti-europeia fundamentalista, nem de um populismo epistêmico em que - conhecimento produzido pelos sujeitos subalternizados sejam automaticamente um conhecimento epistêmico, mas de desvelar o caráter eurocêntrico e hegemônico das ciências ocidentais, evidenciando os epistemicídeos (SANTOS, 2010), e trazer para a superfície os conhecimentos outros que são construídos no contexto da diferença colonial.

Outro diferencial do Pensamento Decolonial é a América Latina como lócus da enunciação. Para essa perspectiva teórica, a América Latina foi primeiro espaço geográfico-cultural onde foi originado um novo padrão/matriz mundial de poder, que Quijano $(2005,2010)$ chama de sistema mundo/moderno-colonial. Dessa 
forma, a AL é uma origem, como foi a Grécia para a civilização ocidental (MIGNOLO, 2003). Para Quental,

A corrente teórica do pensamento decolonial aproxima-se da perspectiva do pós-colonialismo, mas diferencia-se deste campo, entre outros aspectos, justamente por se configurar como teoria elaborada a partir de outro lócus de enunciação: a América Latina, um espaço-tempo constituído a partir de experiências históricas forjadas no colonialismo dos séculos $\mathrm{XVI}$ ao XIX e capitaneados por Espanha e Portugal (2012, p. 47).

A Europa se inventa e cria a América entre os séculos XVI e XVIII, através de relações sociais e de poder baseadas no genocídio, etnocídeo, epistemicídeo, na escravidão, servidão, esbulho de terras, exploração das riquezas naturais, e que são as bases do sistema-mundo moderno que começa a existir. Segundo Porto-Gonçalves,

a Europa só se afirma como centro geopolítico e cultural do mundo moderno a partir da constituição da América enquanto periferia colonial (1492) com seu ouro e sua prata; com sua tropicalidade, condição natural favorável, mas não suficiente, sabemos, para o plantio da cana, do cacau, do algodão, do café, da banana, ou para a coleta da canela, da borracha, do caucho; com o braço escravo modernamente implantado ou com a servidão indígena modernamente direcionada para atender aos ditames do conquistador. É preciso considerar os dois lados dessa geografia que constitui o "sistema-mundo modernocolonial" e, definitivamente, abandonarmos a idéia de uma Modernidade que se constituiu isoladamente na Europa sem que se considere o papel que a América, enquanto colônia, teve na constituição do que se viria ser chamado e, paradoxalmente idolatrado, Modernidade (2003, p. 45).

Portanto, é a partir da criação da América que a Europa funda-se como centro geopolítico do mundo, e entre os séculos XIX e XX com as elites crioulas ${ }^{i i i}$ e o Estado nacional instalados, será consolidada como Latina caracterizada como: politicamente instável; estrutura produtiva atrasada; dependente do capitalismo internacional; com crescimento demográfico acentuado; estrutura fundiária reorganizada pelo capitalismo monopolizado, e com uma população culturalmente atrasada cuja forma de produzir, sistematizar e publicizar conhecimento é dependente da Europa e da América do Norte. A latinidade foi um projeto da França que no século XIX quis recuperar a sua liderança em 
relação a Itália, Portugal e Espanha, com o objetivo de enfrentar a união anglosaxônica (protestante) e latina (católica), ou seja, a escolha de um nome não é puramente semântica, e nominativa, pelo contrário, envolve realidades históricas concretas e específicas, nesse sentido, Quental acrescenta que

o conceito de América e, posteriormente, América Latina, é uma construção semântica com implicações políticas, econômicas, epistêmicas e éticas que surgiu e se impôs, em detrimento de conceitualizações e denominações originárias deste mesmo continente" (2012, p. 55).

Dessa forma, a América Latina é um espaço/tempo criado na relação Modernidade-Colonialidade. Segundo Mignolo, a Colonialidade do Poder é acima de tudo um lugar de enunciação epistêmica onde se descreve e se legitima o poder, para isso classifica "grupos de gentes o poblaciones e identificarlos em sus faltas o excesos, lo cual marca la diferencia y la inferioridade com respecto a quien classifica" (MIGNOLO, 2003, p. 39). Nesse processo de classificação, a colonialidade produz e reproduz Diferença Colonial.

A Diferença Colonial é o espaço e tempo em que se articula a Colonialidade do Poder e "es también el espacio em el que se está verificando la restituión del conocimiento subalterno y está emergiendo el pensamento fronteirizo" (MIGNOLO, 2003, p. 08). A Diferença Colonial opera em duas direções rearticulando e legitimando os saberes coloniais, mas, ao mesmo tempo, possibilita que os saberes Outros, se articulem e reivindiquem seu lugar e tempo na história configurando a Diferença Colonial de novos significados.

A Diferença Colonial é, portanto, um espaço de disputa, e dessa forma podem ser criadas as condições para o desenvolvimento de diálogos em que "una enunciación fracturada es representada desde la perspectiva subalterna como repuesta al discurso y a la perspectiva hegemónica", ou seja, uma epistemologia "de la diferencia colonial que discurre paralelamente a la epistemología de la mismidad" (MIGNOLO, 2003, p. 112).

Portanto, a América Latina como resultante da Colonialidade do Poder, como espaço onde a diferença colonial se produz e reproduz-se, é também local de disputa e resistência, palco de processos de lutas contra-hegemônicas, com uma pluralidade étnico-cultural rica e diversa, onde as populações ancestrais com 
seus sistemas econômicos, políticos e cosmologias ressignificadas, "enunciación fracturada" "de perspectiva subalterna" no contexto da diferença colonial (MIGNOLO, 2003, p. 112), tem desempenhado papéis importantes, de onde desponta uma rica produção intelectual de confronto com as amarras do modelo eurocêntrico de produção do conhecimento, modos de vida e subjetividades.

O Pensamento Decolonial também é tributário da concepção de world-system desenvolvida por Immanuel Wallerstein, durante a década de 1970. Para Wallerstein, as sociedades não estavam divididas em mundos: primeiro, segundo e terceiro, como predominava o pensamento desenvolvimentista da época, tomando como base os níveis de atividade capitalista, industrialização e urbanização. Baseado nisso acreditava-se que a solução para o subdesenvolvimento do suposto Terceiro Mundo era mais capitalismo, indústrias e urbanização. Entretanto Wallerstein, conforme afirma Giddens,

rejeitou essa forma dominante de categorizar as sociedades, argumentando que existe apenas um mundo e que todas as sociedades estão conectadas por meio de relações econômicas capitalistas. Ele descreveu essa complexa interligação de economias como sistema mundial moderno (2012, p. 103).

Para Wallerstein, a origem do sistema mundial moderno é encontrada no século $\mathrm{XVI}$ quando alguns países da Europa em busca de rotas mais curtas para o Oriente, foram vítimas de um erro náutico levando-os a invasão e colonização da América, originando a exploração dos países invadidos, enquanto enriquecia os colonizadores. Para o autor, isso produziu um sistema mundial articulado e interdependente composto de um centro, uma periferia e uma semiperiferia, segundo Quijano e Wallerstein,

the modern world-system was born in the long sixteenth century. The Americas as a geosocial construt were born in the long sisteenh century. The creation of this geosocial entity, the Americas, was the constitutive act of the modern world-sistem. The Americas were not incorporated into an already existing capitalist world-economy. There could not have been a capitalist world-economic without the Americas (1992, p. 549).

Como pode ser observado, a invasão da América é o marco fundacional da economia-mundo, que funciona como um sistema pelo fato de ser mais amplo 
do que qualquer unidade política e econômica, mesmo que dentro de seus limites contenham múltiplos sistemas políticos, Estados, ou seja, o modelo econômico capitalista, está centrado no fato de que os fatores econômicos operam no seio de uma arena maior do que qualquer entidade política possa controlar (ARRUDA, 1983). O que vincula suas partes são laços eminentemente econômicos. Esse sistema econômico está baseado no modo de produção capitalista que Wallerstein entende como dominante e único, tendo em vista que os demais modos de produção pré-capitalistas só puderam continuar sobrevivendo em função da sua adaptação à nova situação criada por essa etapa inicial do capitalismo. Segundo Quijano e Wallerstein (1992), na história da humanidade foram construídas experiências diferentes de Sistemas-Mundo havendo pelo menos duas variantes de modelo: os impérios mundiais e as economias mundiais. No império mundial (Império Mundo) há um único centro político, com uma pesada estrutura burocrática e a divisão de trabalho centralizada, atuando sobre culturas variadas, como o grande Império Romano. $\mathrm{Na}$ economia mundial (Economia Mundo), há vários centros políticos, com divisão de trabalho centralizada, operando em diferentes culturas.

Adotando a concepção marxista da história, Wallerstein compreende que no sistema mundo capitalista há uma intensa divisão do trabalho, que é ocupacional e também geográfica e funciona em "função dos fatores econômicos e evoluí no contexto dos conflitos de classe, assim, a periferia do mundo seria a classe operária e o núcleo a classe exploradora" (GIDDENS, 2012, p. 103).

Quijano $(2005,2010)$ faz uma crítica à concepção de world-system elaborado pelo sociólogo Immanuel Wallerstein. A crítica básica é que ao analisar a expansão colonial europeia no século XV, a partir dos cânones da ciência moderna, o world-system privilegia o aspecto econômico e coloca os demais elementos que constituíram a invasão europeia na América como consequência da implantação do capitalismo. Nessa perspectiva, o sistema econômico que se instalou na América a partir de 1492 determina o comportamento dos sujeitos sociais, através da lógica econômica da acumulação do capital em vista da obtenção de lucro, "manifestando-se na extração de excedentes e na incessante acumulação de capital mundial, originando-se a partir deste contexto, uma 
estrutura social de classe, dessa forma as relações econômicas são privilegiadas e realçadas em detrimento das relações sociais" (GROSFOGUEL, 2010, p. 462). Quijano $(2005,2010)$ reconfigura a ideia original de sistema-mundo-moderno de Wallerstein, pensando agora como "sistema-mundo moderno/colonial". O diferencial do pensamento de Quijano é identificar como no processo de invasão de Abya Yala e a constituição da América Latina, os povos que tiveram seus territórios invadidos e suas riquezas usurpadas também foram considerados, pelo conquistador, como seres humanos inferiores. Para isso, criou-se a "categoria mental" raça que serviu, a partir desse momento, "para codificar e hierarquizar a humanidade em superiores e inferiores" (QUIJANO, 2005, p. 119). A ideia de raça articulou-se a mais dois elementos que caracterizam o novo padrão mundial de poder: a) as várias formas de controle da produção, sua apropriação e distribuição, tais como: a pequena produção mercantil e a reciprocidade foram transformadas em produtos, visando o mercado mundial; e, b) as formas de exploração do trabalho, tais como: escravidão, servidão, assalariamento, foram organizadas e articuladas para produzir mercadoria e transformadas em relação capital-salário. Por fim, as atribuições/lugar/papel dos sujeitos envolvidos no processo de produção de mercadorias foram distribuídas a partir da sua "raça". Quijano exemplifica, assim, essa nova divisão social/racial do trabalho:

na área hispânica, a Coroa de Castela logo decidiu pelo fim da escravidão dos índios, para impedir seu total extermínio. Assim, foram confinados na estrutura da servidão. Aos que viviam em suas comunidades, foi-lhes permitida a prática de sua antiga reciprocidade, isto é, o intercâmbio de força de trabalho e de trabalho sem mercado-como uma forma de reproduzir sua força de trabalho como servos. Em alguns casos, a nobreza indígena, uma reduzida minoria, foi eximida da servidão e recebeu um tratamento especial, devido a seus papéis como intermediária com a raça dominante, e lhe foi também permitido participar de alguns dos ofícios nos quais eram empregados os espanhóis que não pertenciam à nobreza. Por outro lado, os negros foram reduzidos à escravidão. Os espanhóis e os portugueses, como raça dominante, podiam receber salários, ser comerciantes independentes, artesãos independentes ou agricultores independentes, em suma, produtores independentes de mercadorias. Não obstante, apenas os nobres podiam ocupar os 
médios e altos postos da administração colonial, civil ou militar (2005, p. 121).

Dessa forma, produzindo identidades raciais historicamente novas, atribuindoIhes papéis e lugares sociais hierarquizando-os como superiores e inferiores, articulando as diversas formas históricas de controle do trabalho, de seus recursos e de seus produtos, em torno do capital e do mercado mundial, cria-se a América Latina e com ela um novo padrão/matriz colonial de poder. Por isso, Grosfoguel argumenta que "o que chegou as Américas foi uma enredada estrutura de poder mais ampla e mais vasta, que uma redutora perspectiva econômica que a teoria do sistema-mundo" (2010, p. 463), ou modos de produção, e a Economia Política não são capazes de explicar. Portanto, a invasão e a invenção da América são uma origem, "tão origem" como foi a Grécia para a civilização ocidental (MIGNOLO, 2003, p. 57).

Para Dussel (2005), a América não somente foi a primeira periferia do sistemamundo como também a primeira oportunidade de acumulação primitiva do capital. Dessa forma, a inserção do elemento colonial/racial/moderno na noção de sistema-mundo de Wallerstein permitiu entender esse novo padrão/matriz mundial do poder onde raça e racismo são elementos constitutivos, e não apenas superestruturais ou instrumentais para a lógica da acumulação capitalista em escala mundial.

Além dessa relação raça-trabalho, a racialização também possibilitou que o invasor europeu denominasse e classificasse os modos de vidas, os saberes, as formas de explicar o universo, as relações sociais e com a natureza dos povos originários como primitivas, atrasadas, bárbaras, mitos, superstição etc. Como raça inferior não produziam conhecimento e não tinham culturas, dessa forma estavam na infância da humanidade e deveriam passar, mesmo que às custas de extermínio, para o estágio civilizatório.

\section{Considerações Finais}

Portanto, foi com a invasão de Abya Yala e a invenção da América Latina e da categoria raça, e não classe, como princípio articulador e organizador da produção e distribuição das riquezas, somado à razão eurocêntrica produzindo e disseminando conceitos e categorias pretensamente universais, que surge 
esse novo padrão/matriz mundial de poder, que permitiu ao Projeto Moderno eurocêntrico se tornar hegemônico mundialmente. Esse padrão/matriz mundial de poder não diz respeito apenas ao fator econômico ou cultural, mas a um complexo

enredamento de múltiplas e heterogêneas hierarquias globais de forma de dominação e exploração sexual, política epistêmica, econômica, espiritual, linguística e racial, em que a hierarquia étnico-racial reconfigura transversalmente todas as outras estruturas globais de poder, que a teoria marxista, nem a concepção de sistema mundo, conseguem identificar (GROSFOGUEL, 2010, p. 473).

O Projeto Moderno e eurocêntrico é um fenômeno eminentemente europeu e não planetário, mas que se tornou hegemônico pela colonialidade do poder, compondo-se a partir desse contexto como um novo paradigma de vida cotidiana, de compreensão da história, da ciência e da religião. Nesse novo paradigma, a Europa se apresenta como a civilização moderna e se autodescreve como superior e desenvolvida, como o novo e o mais avançado da espécie humana, enquanto que os demais povos são atrasados, primitivos, bárbaros e precisam ser "salvos" dessa condição, mesmo que para isso seja necessária à utilização do genocídio, etnocídio, epistemicídeo etc.

Para explicar esse padrão mundial de poder, o Pensamento decolonial utiliza os conceitos de Colonialismo, Colonialidade do Poder e suas dimensões (saber, ser, e da natureza) e Diferença Colonial, entre outros. Estes conceitos são compreendidos a partir e através da história dos povos indígenas na América Latina.

Torna-se um desafio para nós pesquisadores buscar compreender como os povos originários desse continente ao terem seus territórios e modos de vida invadidos, riquezas usurpadas, considerados em estágio inferior da história da humanidade sendo destituídos de sua condição epistêmica, continuam existindo até os dias atuais reivindicando direitos políticos, culturais e epistêmicos. 


\section{Referências}

ARRUDA, José Jobson de Andrade. Immanuel Wallerstein e o moderno sistema mundial. Revista de História, [S.I.], n. 115, p. 167-174, dez. 1983. Disponível em: <http://www.revistas.usp. br/revhistoria/article/view/61800>. Acesso em: 03 Jul. 2014. doi:http://dx.doi.org/10.11606/issn.2316-9141.v0i115p167-174.

BALLESTRIN, Luciana. América Latina e o giro Decolonial. Revista Brasileira de Ciência Política. N. 11, May/Aug. Brasília, 2013. Disponível em:

<http://dx.doi.org/10.1590/S0103-33522013000200004>. Acesso em agosto de 2013.

\section{CARVALHO, Rosangela Tenório. Discursos pela interculturalidade no campo} curricular da educação de Jovens e Adultos no Brasil. Recife: Bagaço, 2004.

CASTRO-GOMEZ, Santiago; MENDIETA, Eduardo. "Introduccion: la translocalizacion discursiva de Latinoamerica en tiempos de la globalizacion". In: CASTRO-GOMEZ, Santiago; MENDIETA, Eduardo (Coord.). Teorías sin disciplina: latinoamericanismo, poscolonialidad y globalización en debate. Mexico: Miguel Angel Porrua, 1998.

CASTRO-GOMEZ, Santiago. Ciências sociais, violência epistêmica e o problema da 'invenção do outro'. In: LANDER, Edgardo (Org.). A colonialidade do saber: eurocentrismo e ciências sociais, perspectivas latino-americanas. Buenos Aires: Clacso, 2005a.

CASTRO-GÓMEZ, Santiago. La Poscolonialidad explicada a los niños. Bogotá: Universidad del Cauca y Instituto Pensar, 2005b.

CASTRO-GOMEZ, Santiago; GROSFOGUEL, Ramón (Eds). El Giro Decolonial. Reflexiones para una diversidad epistémica más allá del capitalismo global. Bogotá: Universidad Javeriana-Instituto Pensar, Universidad Central-IESCO, Siglo del Hombre, 2007.

DUSSEL, Enrique. Europa, Modernidade e Eurocentrismo. In: LANDER, Edgardo (Org.). A colonialidade do saber: eurocentrismo e ciências sociais, perspectivas latino-americanas. Buenos Aires: Clacso, 2005.

DUSSEL, Enrique. 1492: el encubrimiento del otro: hacia el origen del mito de la modernidad. Facultad de Humanidades y Ciencias de la Educación: Plural Editores. La Paz, 1994. Disponível em: http://bibliotecavirtual.clacso.org.ar/clacso/otros/20111218114130/1942.pdf.

GIDDENS, Antony. Sociologia. 6. ed. São Paulo: Artmed, 2012.

GROSFOGUEL, R. Para descolonizar os estudos de economia política e os estudos pós-coloniais: transmodernidade, pensamento de fronteira e colonialidade global. In: SANTOS, Boaventura de Souza; MENEZES, Maria Paula (Org.). Epistemologias do Sul. Coimbra, Portugal: Cortez, 2010.

MENSAGEIRO Revista - Ameríndia Ontem e Hoje. Estudo no. 4. Edição no. 52 Julho/Agosto (circulação Interna) 1988. 
MIGNOLO, Walter. "La opcion decolonial: desprendimiento y apertura. Un manifiesto y un caso". Tabula Rasa, Bogotá, 2008, n.8, p. 243-282.

MIGNOLO, Walter. Desobediência epistémica. Retórica de la modernidad, lógica de la colonialidad, y gramática de la descolonialidad. Buenos Aires: Ediciones del Signo, 2010.

MIGNOLO, Walter. Historias locales-diseños globales: colonialidad, conocimientos subalternos y pensamiento fronterizo. Madrid: Akal, 2003.

NEVES, Rita Ciotta. Os Estudos Pós-Coloniais: um Paradigma de Globalização. Babilónia. Revista Lusófona de Línguas, Culturas e Tradução, №. 6-7, 2009, pp. 231-239. Universidade Lusófona de Humanidades e Tecnologias. Portugal.

PORTO-GONÇALVES, Carlos Walter. A geograficidade do social: uma contribuição para o debate metodológico sobre estudos de conflito e movimentos sociais na América Latina. En publicación: Movimientos sociales y conflictos en América Latina. José Seoane. CLACSO, Consejo Latinoamericano de Ciencias Sociales, Buenos Aires, Argentina. Programa OSAL, 2003. 288 p.

QUENTAL, Pedro de Araújo. A latinidade do Conceito de América Latina. GEOgraphia, v. 14, No 27, 2012. Disponível em: http://www.uff.br/geographia/ojs/index.php/geographia/article/view/520. Acesso dezembro de 2013.

QUIJANO, Anibal; WALLERSTEIN, Immanuel. Americanity as a Concepto, or the Americas in the Modern World-System. 1992, pp 547- 557.

QUIJANO, Anibal. Colonialidade do poder, eurocentrismo e América Latina. In: LANDER, Edgardo (Org.). A colonialidade do saber: eurocentrismo e ciências sociais. Perspectivas latinoamericanas. Tradução de Júlio César Casarin Barroso Silva. Buenos Aires: CLACSO, 2005.

QUIJANO, Anibal. Colonialidade do Poder e Classificação Social. In: SANTOS, Boaventura de Souza; MENEZES, Maria Paula (orgs.). Epistemologias do Sul. Coimbra, Portugal: Cortez Editora, 2010. p. 84 - 130.

QUIJANO, Aníbal. Colonialidad y modernidad-racionalidad. In: Los conquistados. 1492 y la población indígena de las Américas, edição Heraclio Bonilla: Tercer Mundo-Libri Mundi, Bogotá, 1992, pp. 437-447.

SANTOS, Boaventura de Souza. Para Além do pensamento abissal: das linhas globais a uma ecologia dos saberes. In: SANTOS, Boaventura de Souza; MENEZES, Maria Paula (Org.). Epistemologias do Sul. Coimbra, Portugal: Cortez Editora, 2010. p. 3183.

\footnotetext{
i Os povos que viviam na parte de mundo que ficou conhecida mundialmente como América Latina atribuíam nomes próprios às regiões que ocupavam, tais como: Abya Yala, Tawantinsuyu, Anauhuac, Pindorama. "Abya Yala" era como os Kuna chamavam a América; "Terras Guarani" (envolvendo parte da Argentina, do Paraguai, sul do Brasil e Bolívia), Tawantinsuyu (a região do atual Peru, Equador e Bolívia), Anahuac (região do atual México e Guatemala), Pindorama (nome com que os Tupi designavam o Brasil), entre outras cartografias. A expressão Abya Yala que na língua do povo Kuna da Colômbia, significa Terra madura,
} 
Terra Viva ou Terra em florescimento vem sendo utilizado pelos movimentos dos povos originários do continente como uma autodesignação em contraposição a América, objetivando construir um sentimento de unidade e pertencimento. A primeira vez que a expressão foi explicitamente usada com esse sentido político foi na II Cumbre Continental de los Pueblos y Nacionalidades Indígenas de Abya Yala, realizada em Quito, em 2004 (PORTO-GONÇALVES, 2009

ii Grosfoguel (2010) utiliza a expressão Enredo para analisar e explicar que a estrutura de poder que chegou às Américas em 1492 foi mais ampla e mais vasta que as perspectivas economicistas da Economia Política ou o Sistema Mundo Moderno adotam para analisar os eventos que ocorreram nesse período.

iii Estamos tratando elite colonial, os grupos ou pessoas descendentes de portugueses ou espanhóis que, assumiram o controle da economia, da autoridade, do conhecimento e deu continuidade à política imperial com relação aos africanos e indígenas na América Latina (MIGNOLO, 2010). 